\title{
Editorial \\ 50 fascicles of Folia Cryptogamica Estonica- a journey from single pages to an established journal
}

\author{
Tiina Randlane \\ Institute of Ecology and Earth Sciences, University of Tartu, Lai St. 38/40, 51005 Tartu, Estonia. \\ E-mail: tiina.randlane@ut.ee
}

The 1st fascicle of Folia Cryptogamica Estonica (FCE) was published on April 15, 1972 in Tartu, as the starting point of a new aperiodic series by the Naturalists' Society at the Academy of Sciences of the Estonian SSR. The series was going to distribute papers on taxonomy, geography and ecology of fungi, algae and lichens. This 1st fascicle (like following 22) was printed on rather yellowish paper and consisted of 8 pages, clipped with two staples. The first editors were Ain Raitviir (Editor-in-Chief, responsible for mycology), Jaan Toom (algology) and Hans Trass (lichenology). The same editing team produced during 15 years, in 1972-1986, 23 fascicles of FCE, mainly of 8 pages, with rather unstable printing and paper quality, if one were to look at these folia from the point of view of the contemporary printing techniques. The publishing activities were somewhat sporadic, e.g. 1 fascicle was published in 1972, 1973 and 1978; 2 - in 1972 and 1986; 3 - in 1974 and 1977; 4 - in 1985; and 5 in 1981, while none came out in 1975, 1976, 1979, 1980, 1982-1984. Many odd mistakes occurred as no-one from the editing team was really trained in editing or publishing. For instance, fasc. 20 and 21 came out of print in 1986, while fasc. 22 and 23 were published in the previous year, 1985. The papers were written either in Russian with English summaries, or in English with Russian summaries; typing errors or grammatical mistakes were not uncommon. However, on these 23 yellowish folia, badly printed and unprofessionally designed, altogether 62 papers by ca 20 Estonian authors were published presenting nearly 100 taxonomic novelties, incl. 59 new taxa and 40 new combinations (Saag, 2013). Most of the articles offered floristical lists of different localities in Estonia or in other republics of the USSR. A few papers were definitely of wider interest and could be classified nowadays as research articles, such as "Saprobity and evolutionary trends of algae" by Toom (1972), "Lichen sensitivity to the air pollution and index of poleotolerance (I.P.)" by Trass (1973) or "Analysis of the ability of the Hypogymnia physodes to indicate atmospheric pollution in mountainous conditions" by Zobel (1986). Evaluating the impact of the early fascicles of FCE, we should bear in mind that during this period (1970-80ies) almost all scientific literature within the Soviet Union was produced in Russian, and the possibility to publish at least a summary in English was extraordinary and attractive. Furthermore, absolutely every manuscript which was meant to be published, had to pass the political censure. In this field of science - floristics of cryptogams - censure did not practically affect the content of the articles, however, it could delay the publishing process considerably.

The following seven fascicles, 24-30, were published during 1987-1992 by the editing team consisting of Hans Trass (Editor-in-Chief, responsible for lichenology), Kuulo Kalamees (mycology), Erich Kukk (algology) and Külli Tamm (bryology), who was substituted by Mare Leis in 1991. The format and size of fascicles was changed, containing now 16-42 pages, and all papers were presented consistently in English (the Russian summaries were given up in 1989). Changes were in the air in the society, and some of these reflected also in FCE, e.g. fasc. 28 (1991) published the first article of foreign authors (Ekman et al., 1991) in this series, reporting 74 lichen species new for Estonia - as a result of excursions by Swedish lichenologists to Estonia in 1989. 
After fasc. 30 (1992), no issues followed during four years, mainly caused by the economic reasons. In 1997, a new Editor-in-Chief, Urmas Kõljalg, started, assisted by the Associate Editor Andres Saag. Editorial Board consisting of Hans Trass (Chairman), Erast Parmasto (mycology), Tiina Randlane (lichenology) and Nele Ingerpuu (bryology) was established. The format and design of the publication was changed again - a few clipped pages were substituted by a "regular" journal with a soft blue cover, text arranged in two columns, articles provided with Abstracts in English and Estonian. During ten years (19972006), the editors Urmas Kõljalg and Andres Saag produced 13 issues, containing 53-151 pages. Several special volumes were prepared: FCE 32 - "Lichens in Estonia and in the rest of the world", papers dedicated to Hans Trass on his 70th birthday (1998); FCE 33 - "Taxonomy and phylogeny of Homobasidiomycetes", papers dedicated to Elmar E. Leppik and Erast Parmasto (1998); FCE 35 - "Second checklist of lichenized, lichenicolous and allied fungi of Estonia" (1999); FCE 41 - "Lichens in Focus", selection of poster contributions of IAL5 (2005).

In 2007, the Editor-in-Chief, Urmas Kõljalg, withdrew and the job was accepted by Andres Saag who is currently running the editing. Next year, 2008, fasc. 44 acquired a new appearence once again - the cover was re-designed and exhibits now a colourful photo of lichens and mosses on alvar soil. The online version (ISSN 1736-7786; http:/ /www.ut.ee/ial5/fce) was established - earlier fascicles have been scanned; fasc. 31-42 are available as complete pdf-files, and starting from fasc. 43 each paper is available as a separate pdf-file. FCE is currently included in several databases, e.g. EBSCO, Recent Literature on Lichens and Scopus. The publication is now produced by the University of Tartu Press, and supported by both the Estonian Naturalists' Society and the University of Tartu. The circle of contributing authors has changed considerably and become international: our permanent authors come, besides Estonia, from Denmark, Finland, Germany, Latvia, Lithuania, Poland, Sweden, and Russia; but papers also from other European countries and other continents have been submitted and published. Similarly, the Editorial Board (besides the local members of the Board, Seppo Huhtinen from Finland, Ernestas Kutorga from Lithuania, Anders Nordin from Sweden and Lars Söderström from Norway are currently involved) and the circle of reviewers have become international. The process of revising and accepting the papers is more complicated (each manuscript is revised by at least one invited reviewer and one Member of the Editorial Board) but, hopefully, resulting in better quality. Here the Editorial Board would like to thank all our authors who have submitted their manuscripts into FCE, and all our reviewers who have spent their time and efforts to revise and improve the submitted papers.

Folia Cryptogamica Estonica will carry on with the next fifty fascicles. It is clear that the title of the journal has become outdated - none of the words actually apply any longer - the journal does not consist of few single folia nowadays; the term "cryptogam" is old-fashioned and not taxonomic; the circle of FCE subjects, authors and reviewers is not limited to Estonia. However, we continue with this title, for the time being, if only for emotional reasons...

Some numbers about FCE fasc. 1-50:

- 382 papers published on 2575 pages;

- 284 authors representing 35 countries, incl. 66 Estonian authors;

- 237 taxonomic novelties proposed, incl. 136 newly described taxa and 101 new combinations.

\section{REFERENCES}

Ekman, S., Fröberg, L., Kärnefelt, I., Sundin, R. \& Thor, G. 1991. New or interesting lichens from Estonia. Folia Cryptog. Estonica 28: 5-25.

Saag, A. 2013. Taxonomic novelties published in Folia Cryptogamica Estonica, fascicles 1-50. Folia Cryptog. Estonica 50: 125-129.

Toom, J. 1972. Saprobity and evolutionary trends of algae. Folia Cryptog. Estonica 1: 5-8. (In Russian, English summary).

Trass, H. 1973. Lichen sensitivity to the air pollution and index of poleotolerance (I.P.). Folia Cryptog. Estonica 3: 19-22.

Zobel, K. 1986. Analysis of the ability of the Hypogymnia physodes to indicate atmospheric pollution in mountainous conditions. Folia Cryptog. Estonica 28: 4-7. (In Russian, English summary). 